\title{
Cytogenetic analysis of five species of the subfamily Corydoradinae (Teleostei: Siluriformes: Callichthyidae)
}

\author{
Cristiane Kioko Shimabukuro-Dias, Claudio Oliveira and Fausto Foresti \\ Universidade Estadual Paulista, Instituto de Biociências, Departamento de Morfologia, Botucatu, \\ São Paulo, Brazil.
}

\begin{abstract}
In the present study, five callichthyid species belonging to the subfamily Corydoradinae were karyotyped: three species of Aspidoras and two of Corydoras. The three species of Aspidoras had the same diploid number, $2 \mathrm{n}=46$ chromosomes, similar karyotypic formulae, with most chromosomes metacentric or submetacentric, single interstitial Ag-NORs and C-band positive segments mainly found in the centromeric position. The comparative analysis of cytogenetic data available for the genus Aspidoras and other species of Corydoradinae suggest that several events of centric fusion occurred in the origin of the species of Aspidoras. The two analyzed species of Corydoras showed high diploid numbers, $2 n=74$ in $C$. sodalis and $2 n=90$ in C. britskii. While $C$. sodalis exhibited single Ag-NORs and terminal, interstitial and centromeric C-band positive segments in almost all chromosomes, $C$. britskii showed multiple Ag-NORs and a small number of C-band positive segments found in the terminal position in one acrocentric (A) pair and in the interstitial position in one subtelocentric (ST) pair. The occurrence of high diploid numbers and many ST and A chromosomes are uncommon among the Corydoradinae, suggesting the occurrence of a high number of chromosome rearrangements, mainly centric fissions, in the origin of the Corydoras species studied.
\end{abstract}

Key words: fish cytogenetic, karyotype, NOR, C-banding, karyotypic evolution.

Received: November 20, 2003; Accepted: May 25, 2004.

\section{Introduction}

The family Callichthyidae consists of two subfamilies: Corydoradinae and Callichthyinae (Reis, 2003). The subfamily Corydoradinae, with more than $90 \%$ of the species of the family Callichthyidae, presents 164 valid species divided in three genera: Aspidoras, Brochis and Corydoras (Reis, 1998; Reis, 2003). Phylogenetic studies, based on morphological data, showed that the subfamily Corydoradinae and the genera Aspidoras and Brochis were monophyletic groups while the genus Corydoras was paraphyletic or polyphyletic (Reis, 1998; Britto, 2003, respectively). With the main objective of identifying the monophyletic groups that compose the subfamily Corydoradinae, Britto (2003) proposed a new classification for the group, according to the tribe Aspidoradini, previously constituted only by the genus Aspidoras, is composed of Aspidoras and Scleromystax. The genus Scleromystax is composed of a monophyletic group of four species formerly belonging to the genus Corydoras (C. barbatus, C. macropterus, C. prionotos, and

Send correspondence to Claudio Oliveira. Universidade Estadual Paulista, Instituto de Biociências, Departamento de Morfologia, 18618-000 Botucatu, SP, Brazil. E-mail: claudio@ ibb.unesp.br.
C. lacerdai). The tribe Corydoradini, which included the genera Brochis and Corydoras, is now composed only of the genus Corydoras, and the genus Brochis was considered a junior synonymous with Corydoras (Britto, 2003).

The cytogenetic studies in the subfamily Corydoradinae are concentrated in Corydoras. Oliveira et al. (1992) reviewed the karyotypes and the nuclear DNA content of 29 species of the genus Corydoras and suggested the division of this genus into at least five groups of species based on their diploid number, karyotype and nuclear DNA content. A recent review of the cytogenetic data available for about 46 species of Corydoras (Shimabukuro-Dias et al., 2004) corroborate the hypothesis of Oliveira et al. (1992) about the division of the genus Corydoras into five groups and revealed that the diploid number ranged from $2 \mathrm{n}=40$ chromosomes in Corydoras nattereri (Oliveira et al., 1990; Oliveira et al., 1993b) to $2 \mathrm{n}=134$ in C. aeneus (Turner et al., 1992). This chromosome diversity found in Corydoras is one of the highest found among all fish genera (Scheel et al., 1972; Oliveira et al., 1992; Oliveira et al., 1993a; Oliveira et al., 1993b; Klinkhardt et al., 1995). In the genus Aspidoras, only the species A. fuscoguttatus, with $2 n=44$ chromosomes, had its karyotype described 
(Oliveira et al., 1993a). Cytogenetic studies in the genus Scleromystax were conducted with the species $S$. barbatus $(2 \mathrm{n}=64 / 2 \mathrm{n}=66), S$. macropterus $(2 \mathrm{n}=66)$, and $S$. prionotos $(2 \mathrm{n}=68 / 2 \mathrm{n}=86)$ (Oliveira et al., 1993b).

The main objective of the present study was to gather new cytogenetic data for the genera Aspidoras and Corydoras and thus construct a more robust hypothesis regarding the pattern of relationships between species of the Corydoradinae subfamily. Thus, the karyotype of three species of Aspidoras and two species of Corydoras is described, through the Giemsa staining, staining of nucleolus organizer regions with Silver Nitrate (Ag-NORs) and Cbanding.

\section{Material and Methods}

Cytogenetic studies were conducted with the following species: Aspidoras taurus, three males and one female from the Itiquira River, $17^{\circ} 02^{\prime} 36.3^{\prime \prime} \mathrm{S} 53^{\circ} 28^{\prime} 43.3^{\prime \prime} \mathrm{W}$, Alto Garça, Mato Grosso, Brazil; Aspidoras cf. fuscoguttatus, two males and two females from aquarium; Aspidoras poecilus, four females from the Araguaia River, $17^{\circ} 33^{\prime} 42.4^{\prime \prime} \mathrm{S} 53^{\circ} 18^{\prime} 29.7^{\prime \prime} \mathrm{W}$, Alto Araguaia, Mato Grosso, Brazil; Corydoras sodalis, two males and one female from aquarium; and Corydoras britskii, one male and one female from a tributary of the Piraí River, $16^{\circ} 25.280^{\prime} \mathrm{S}$ $56^{\circ} 25.143^{\prime} \mathrm{W}$, Poconé, Mato Grosso, Brazil. After processing, fishes were identified and stored as vouchers at the fish collection center of Laboratório de Biologia de Peixes (LBP), Instituto de Biociências, Universidade Estadual Paulista, Botucatu, São Paulo, Brazil.

Chromosome preparations were carried out according to Foresti et al. (1993). Silver staining of the nucleolar organizer regions was performed according to the technique proposed by Howell and Black (1981), the C-banding technique was performed as described by Sumner (1972). Chromosome morphology was determined on the basis of arm ratio as proposed by Levan et al. (1964) and chromosomes were classified as metacentric $(\mathrm{M})$, submetacentric (SM), subtelocentric (ST) and acrocentric (A).

\section{Results}

The three studied species of the genus Aspidoras showed $2 \mathrm{n}=46$ chromosomes. The species $A$. taurus (Figure 1a) and $A$. poecilus (Figure 1c) exhibited karyotypic formulae composed of 15 pairs of $\mathrm{M}$ chromosomes, 5 pairs of SM and 3 pairs of ST. The karyotype of the species Aspidoras cf. fuscoguttatus had 16 pairs of M chromosomes, 5 pairs of SM and 2 pairs of ST (Figure 1b). Corydoras sodalis displayed $2 \mathrm{n}=74$ chromosomes, divided into 8 pairs of M chromosomes, 9 pairs of SM, 5 pairs of ST and 15 pairs of A (Figure 2a). Corydoras britskii showed $2 \mathrm{n}=90$ chromosomes and karyotypic formulae constituted by 2 pairs of M chromosomes, 5 pairs of SM, 11 pairs of ST and 27 pairs of A (Figure 2b).
The chromosome analysis with the Ag-NOR technique showed the presence of single marks, interstitially located at the short arms of the fifth $\mathrm{M}$ pair in all species of Aspidoras (Figure 1). Only one of the NOR-bearing chromosomes was marked in A. taurus. C. sodalis showed single Ag-NORs, in terminal position, at the long arms of the fifth pair of A chromosomes (Figure 2a). C. britskii exhibited terminal Ag-NORs at the short arms of the ST chromosome pairs number 14 and 16 (Figure 2b).

The analysis of the C-banding pattern showed that the species $A$. cf. fuscoguttatus (Figure $3 \mathrm{~b}$ ) and A. poecilus (Figure $3 \mathrm{c}$ ) presented large C-band positive segments located at the centromeric position in most chromosomes. $A$. taurus (Figure 3a) exhibited C-band positive segments in the centromeric position in almost all chromosomes and some terminal segments in a few chromosomes. C. sodalis showed C-band positive segments at terminal, interstitial and centromeric positions in many chromosomes (Figure 3d). The species C. britskii presented a small amount of $\mathrm{C}$-band positive segments restricted to the terminal position in one A pair and another at the interstitial position in one pair of ST chromosomes (Figure 3e).

\section{Discussion}

\section{Chromosome evolution in the genus Aspidoras}

The three studied species of the genus Aspidoras showed the same diploid number, $2 \mathrm{n}=46$, and similar, but not identical, karyotypes. Although the species A. taurus and $A$. poecilus presented the same karyotypic macrostructure, their karyotypes were different due to the presence of a higher amount of C-band positive segments in A. taurus. The species $A$. cf. fuscoguttatus exhibited a different karyotypic formulae from those observed in the other species due to its different number of M and SM chromosomes.

Cytogenetic studies conducted with the species $A$. fuscoguttatus, showed that it presented $2 \mathrm{n}=44$ chromosomes $(28 \mathrm{M}+12 \mathrm{SM}+4 \mathrm{ST})$, interstitial Ag-NORs in the long arms of the biggest SM chromosome pair and C-band positive segments distributed in the pericentromeric position in almost all chromosomes (Oliveira et al., 1993a). These characteristics are similar to those found in the three species of Aspidoras analyzed in the present study, which suggest that few chromosome rearrangements - fusions or translocations - occurred during the chromosome evolution of the species of this genus.

The presence of diploid numbers close to $2 n=44 / 46$ was also observed among some species of Corydoras $(C$. nattereri, $C$. ehrhardti, $C$. paleatus, $C$. arcuatus, $C$. schwartzi, C. trilineatus, and C. panda) (Oliveira et al., 1990; Oliveira et al., 1992; Oliveira et al., 1993a; Oliveira et al., 1993b). However, while those species of Corydoras presented large chromosomes (with size variation from 3 $\mu \mathrm{m}$ to $8 \mu \mathrm{m}$ ) and about $4.4 \mathrm{pg}$ of DNA per diploid nuclei 


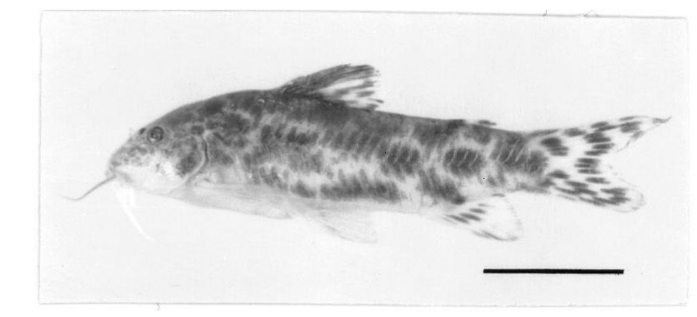

a
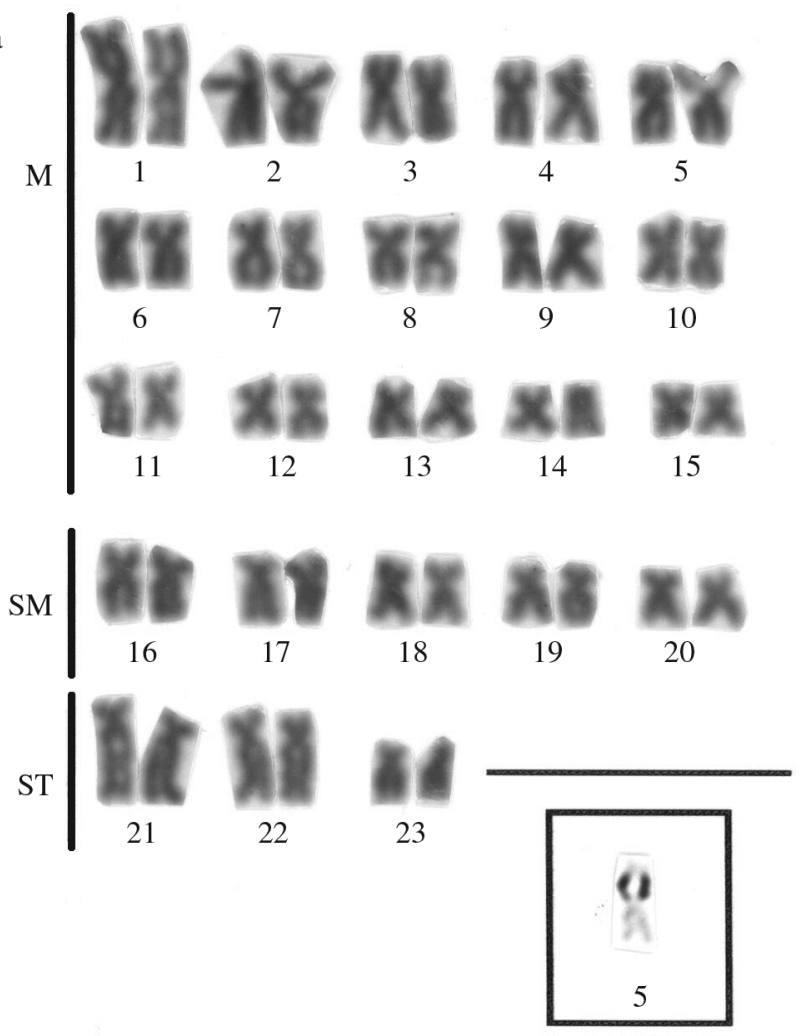

b

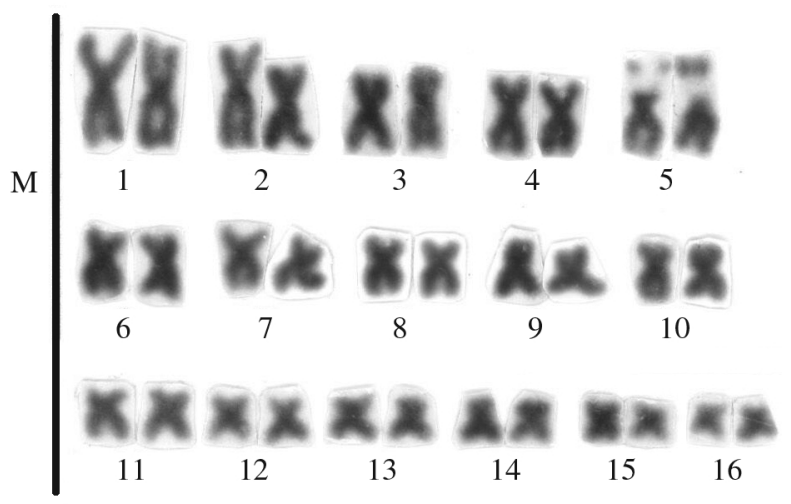

SM
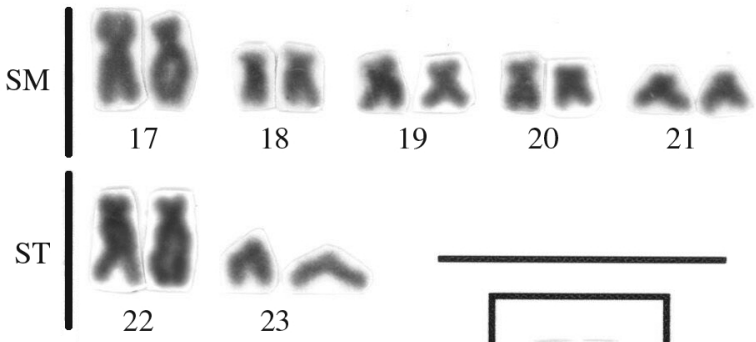

23

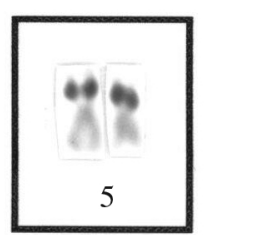

Figure 1 - Karyotypes, Ag-NORs and specimens of: a) Aspidoras taurus, $2 \mathrm{n}=46$ and b) A. cf. fuscoguttatus, $2 \mathrm{n}=46$.

(Oliveira et al., 1992), the species of Aspidoras presented very small chromosomes (with size variation from $1 \mu \mathrm{m}$ to $4 \mu \mathrm{m}$ ) and about $1.5 \mathrm{pg}$ of DNA per diploid nuclei in $A$. fuscoguttatus (Oliveira et al., 1993a; present study).

The low nuclear DNA content observed in $A$. fuscoguttatus (Oliveira et al., 1993a) was also found in the species of the genus Scleromystax (cited as Corydoras), including S. barbatus, S. prionotos, and S. macropterus (Oliveira et al., 1993b), which allow Oliveira et al. (1993a) to propose that these species of Scleromystax could be related to the species of Aspidoras. This hypothesis was corroborated by the phylogenetic study conducted by Britto (2003), that showed that the genera Aspidoras and Scleromystax compose a monophyletic group (the tribe Aspidoradini). The presence of low diploid numbers in Aspidoras $(2 \mathrm{n}=44-46)$ and high diploid numbers in Scleromystax $(2 \mathrm{n}=64-86)$ and other genera of Callichthyidae suggest that several terminal fusions may have occurred in the ancestor which gave origin to the ge- nus Aspidoras as initially proposed by Oliveira et al. (1993a).

In Corydoradinae, interstitial Ag-NORs, as those observed in Aspidoras, were found only in a few species of Corydoras (Oliveira et al., 1990; Oliveira et al., 1992). In other groups of Siluriformes, the presence of interstitial Ag-NORs is uncommon, though it has been described for some species of the families Trichomycteridae (Torres et al., 1998) and Loricariidae (Alves et al., 2003).

The occurrence of large C-band positive segments located at the centromeric position in most chromosomes of the species of Aspidoras is also found in the Corydoras species with $2 \mathrm{n}=44 / 46$ chromosomes as with $C$. nattereri, $C$. ehrhardti, C. paleatus, C. arcuatus, C. schwartzi, C. trilineatus, and C. panda (Oliveira et al., 1990; Oliveira et al., 1992; Oliveira et al., 1993a; Oliveira et al., 1993b). On the other hand, this kind of distribution of C-band positive segments is very different from that observed in the callichthyid species of the genus Scleromystax which are more closely related to Aspidoras, since in the species of 


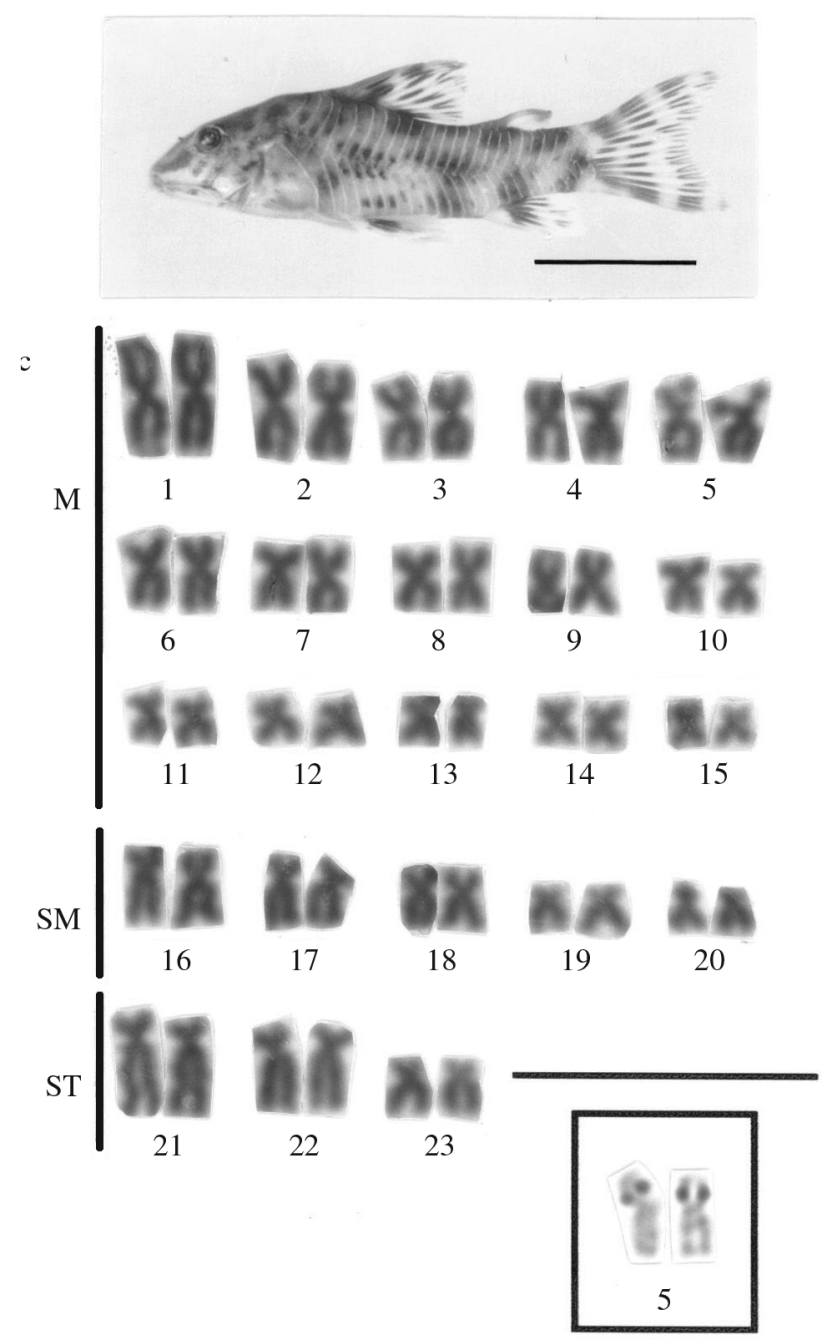

Figure 1 (cont.) - Karyotypes, Ag-NORs and specimens of: c) $A$. poecilus, $2 \mathrm{n}=46$. Scale bars: $10 \mu \mathrm{m}$ (karyotype) and $10 \mathrm{~mm}$ (specimen).

Scleromystax the C-band positive segments were mainly distributed in the short arms of several chromosome pairs (Oliveira et al., 1993b).

Although the cytogenetic studies in the genus Aspidoras have been conducted in about one fifth of the described species, it is possible to observe the remarkable homogeneity in the karyotypes of the species of the genus. Moreover, the set of cytogenetic characteristics found in Aspidoras is not found in any other genera of Callichthyidae, which reinforces the hypothesis that this genus is monophyletic.

\section{Chromosome evolution in the genus Corydoras}

The cytogenetic analysis of the species $C$. sodalis revealed that it presented a high diploid number $(2 n=74)$, a high number of ST and A chromosomes, a single AgNORs-bearing chromosome pair, and small C-band positive segments distributed in all chromosomes. These characteristics are very similar to those found in other species of

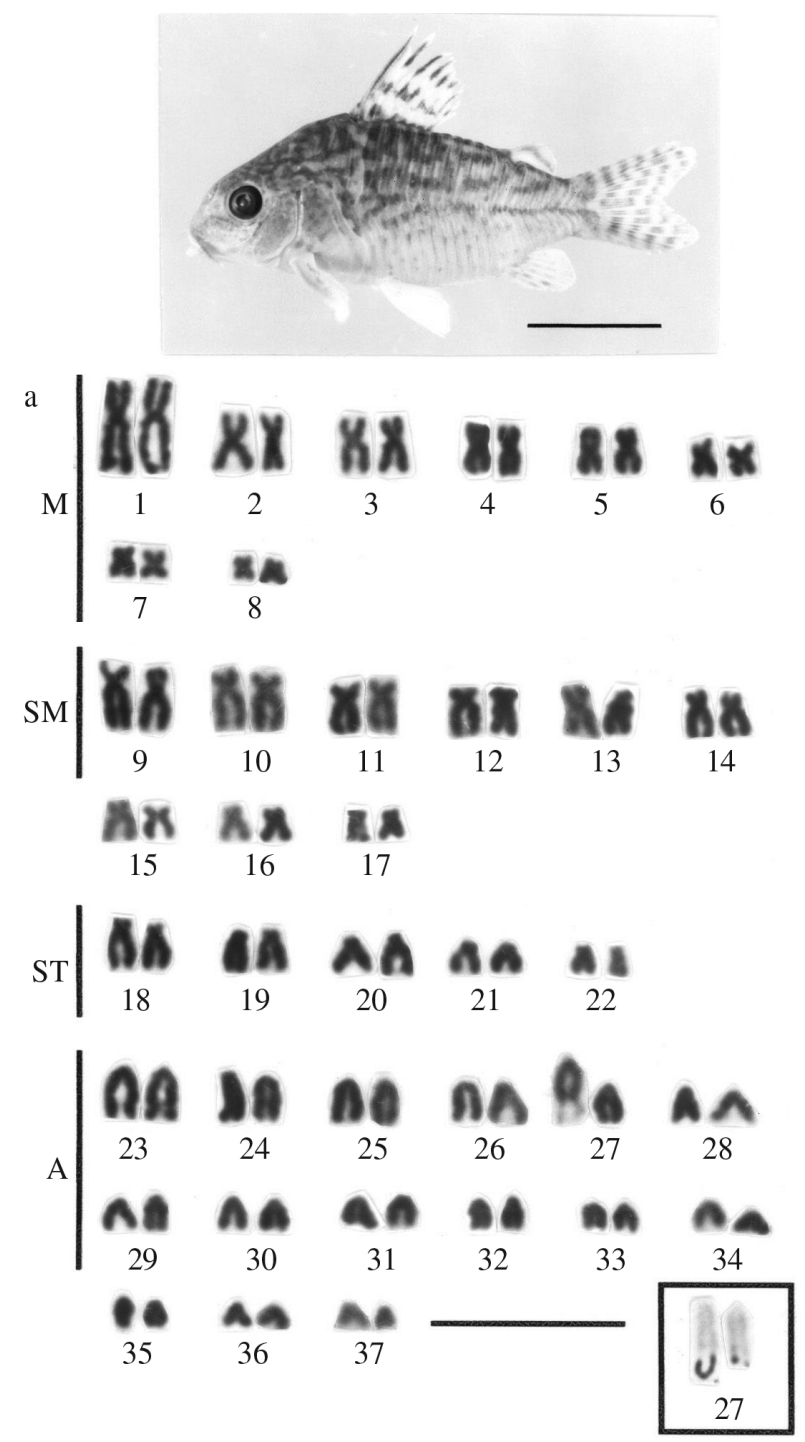

Figure 2 - Karyotypes, Ag-NORs and specimens of a) Corydoras sodalis, $2 n=74$.

Corydoras, as $C$. reticulatus $(2 \mathrm{n}=74)$ (Oliveira et al., $1992)$ and $C$. difluviatilis $(2 \mathrm{n}=78)$ (our unpublished data), suggesting that these species could belong to a natural group, identified as group 2 by Oliveira et al. (1992).

The species $C$. britskii showed the same diploid number and karyotypic formulae described for some specimens studied and identified as Brochis britskii by Oliveira et al. (1993a). However, while in the present study the occurrence of multiple Ag-NORs and C-band positive segments restricted to two chromosome pairs was observed, the sample of C. britskii studied by Oliveira et al. (1993a) showed single Ag-NORs and large C-band positive segments in almost all chromosome pairs. These differences could be attributed to the occurrence of technical problems or to the existence of different cytotypes in this species. Another species, earlier identified as Brochis splendens, and now identified as Corydoras splendens, exhibited $2 \mathrm{n}=100$ 


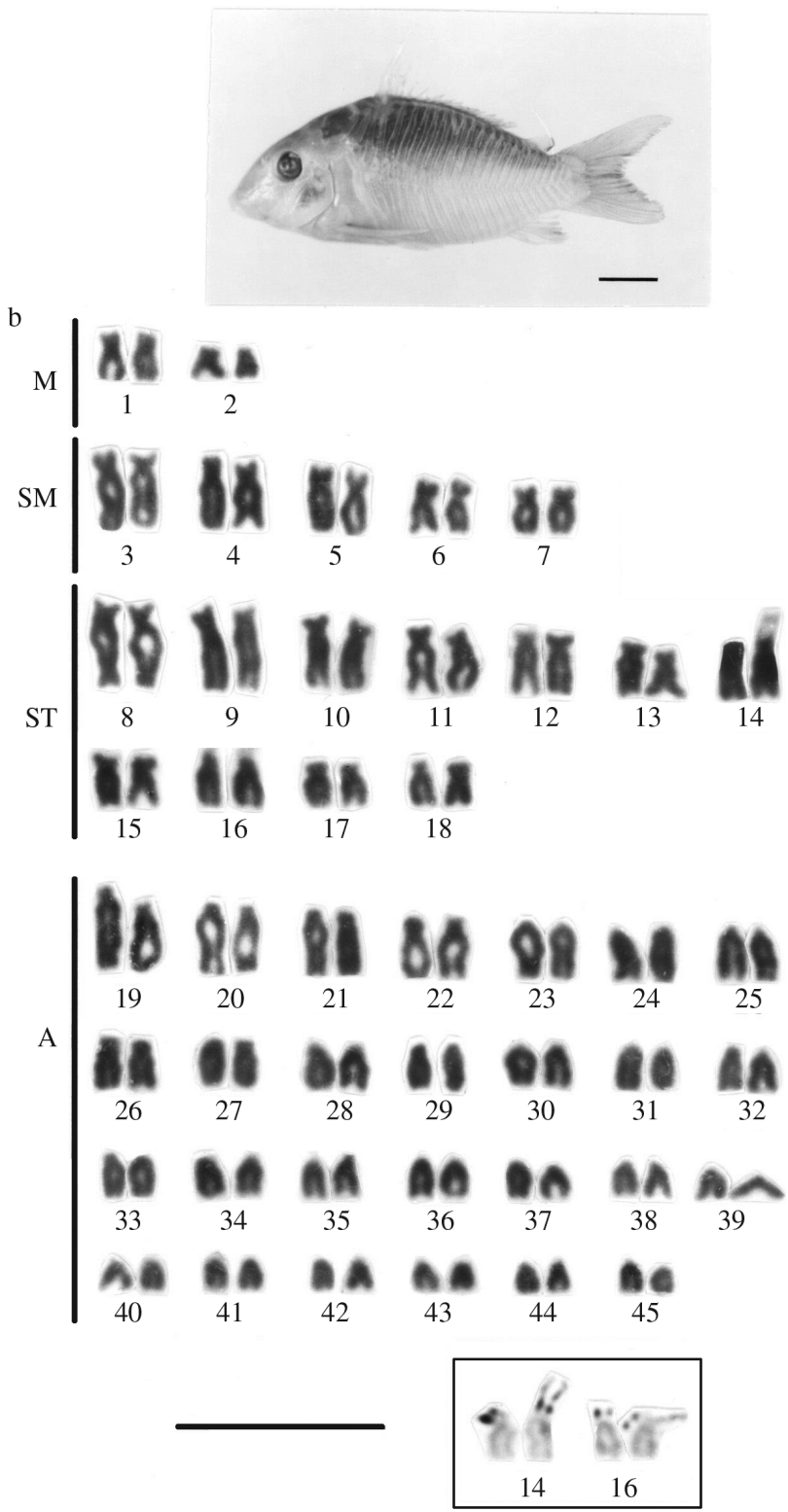

Figure 2 (cont.) - Karyotypes, Ag-NORs and specimens of b) C. britskii, $2 \mathrm{n}=90$. Scale bars: $10 \mu \mathrm{m}$ (karyotype) and $10 \mathrm{~mm}$ (specimen).

chromosomes $(18 \mathrm{M}+18 \mathrm{SM}+20 \mathrm{ST}+44 \mathrm{~A})$, multiple $\mathrm{Ag}$ NORs and centromeric C-band positive segments (Oliveira et al., 1993a). These results show that these two species, formerly placed in the genus Brochis, have many cytogenetic characteristics in common, reinforcing the hypotheses that both belong to a monophyletic group (Reis, 1998; Britto, 2003).

The presence of high diploid numbers (greater than $2 \mathrm{n}=70$ ) and a high number of ST and A chromosomes, found in several species of Corydoras (Oliveira et al., 1992), and also observed in C. britskii and C. sodalis analyzed in the present study, reinforce the hypotheses that these two species belong to a natural group (Oliveira et al., 1993a). In the only phylogenetic study based on morpho-

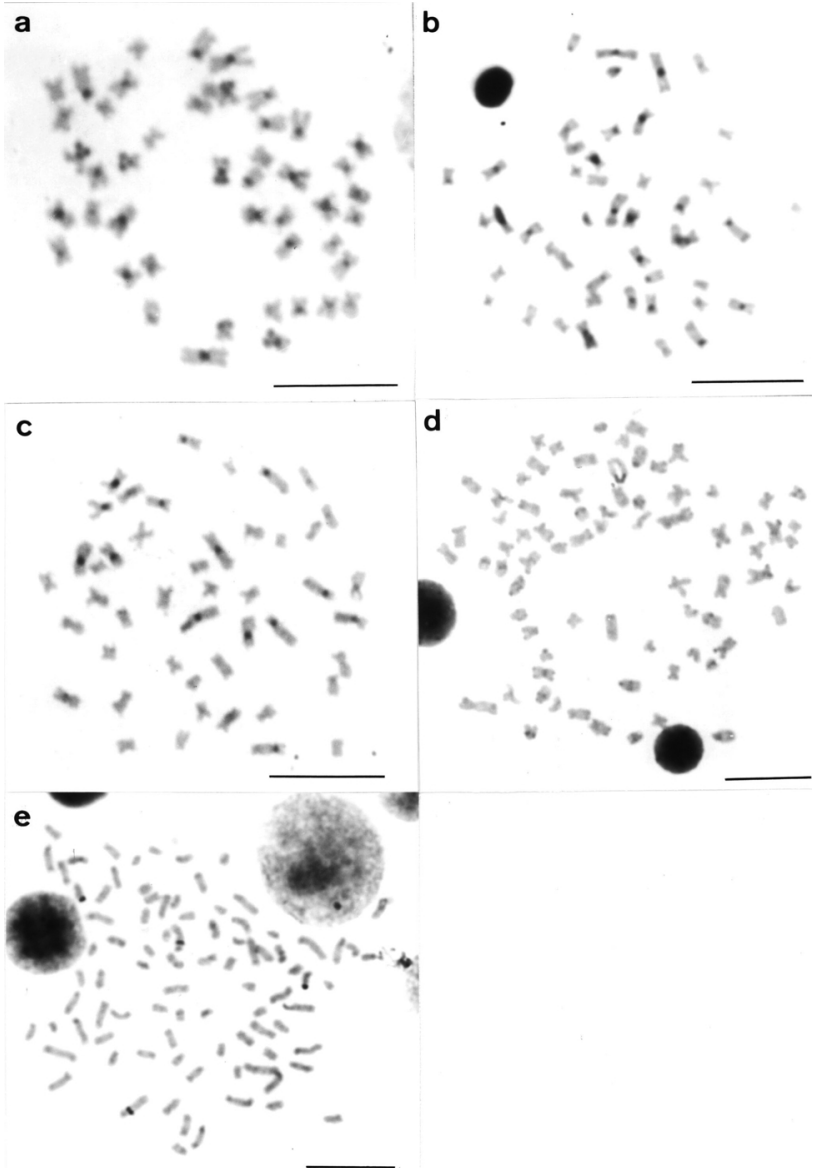

Figure 3 - Somatic metaphases treated with C-banding technique. a) Aspidoras taurus; b) A. cf. fuscoguttatus; c) A. poecilus; d) Corydoras sodalis; and e) C. britskii. Bars $=10 \mu \mathrm{m}$.

logical characters of a high number of species of Corydoradini, conducted by Britto (2003), a close relationship among the species $C$. difluviatilis (cited as Corydoras sp. by Britto, 2003), C. reticulatus, and C. britskii (cited as Brochis britskii by Britto, 2003) was not observed. The species $C$. sodalis was not included in the analysis of Britto (2003).

The presence of single Ag-NORs in C. sodalis and multiple Ag-NORs in C. britskii, as observed in the present study, were also described for other species of Corydoras, reinforcing the hypothesis that these species belong to a natural group, group 2 from Oliveira et al. (1992). The Ag-NORs, in the analyzed species of Corydoras, exhibited a large size polymorphism. This characteristic has been found in many species of Neotropical fish, and it may be due to the occurrence of duplication in the ribosomal DNA sequences, caused by unequal crossing-over rearrangements during meiosis (Almeida-Toledo et al., 2000). The distribution patterns of C-band positive segments in $C$. sodalis and $C$. britskii have also been observed in other species of Corydoras of group 2 from Oliveira et al. (1992). 
The presence of high diploid numbers and a high number of ST and A chromosomes, found in some species of the genus Corydoras, are uncommon characteristics in the family Callichthyidae (Oliveira et al., 1993a) and even in other families of Siluriformes as well (Oliveira and Gosztonyi, 2000). Thus, it seems that in the origin of this group of species of Corydoras a high number of chromosome rearrangements - such as centric fissions - occurred, contrary to what occurred in the genus Aspidoras, in which a high number of chromosome fusions could have occurred. Moreover, the differences in the number and position of Ag-NORs and in the amount and distribution of C-band positive segments observed among species of Corydoradinae suggest that, besides the large morphological changes, which occurred in the karyotype, several small changes in the chromosomes also occurred in the evolutionary history of the group.

\section{Acknowledgments}

The authors would like to thank Renato Devidé for his technical assistance, Paulo C. Vênere for his valuable help in the collection of some specimens, and Marcelo R. Britto for the identification of the specimens. The authors would also like to thank FAPESP and CNPq for their financial support.

\section{References}

Almeida-Toledo LF, Foresti F and Toledo-Filho SA (2000) Karyotypic evolution in Neotropical fish. Chromosomes Today 13:169-182.

Alves AL, Oliveira C and Foresti F (2003) Karyotype variability in eight species of the subfamilies Loricariinae and Ancistrinae (Teleostei, Siluriformes, Loricariidae). Caryologia 56:57-63.

Britto MR (2003) Phylogeny of the subfamily Corydoradinae Hoedeman, 1952 (Siluriformes: Callichthyidae), with a definition of its genera. Proc Acad Nat Sci Philad 153:119-154.

Foresti F, Oliveira C and Almeida-Toledo LF (1993) A method for chromosome preparations from large specimens of fishes using in vitro short treatment with colchicine. Experientia 49:810-813.

Howell WM and Black DA (1981) Controlled silver staining of nucleolus organizer regions with a protective colloidal developer: A 1-step method. Experientia 36:1014-1015.

Klinkhardt M, Tesche M and Greven H (1995) Database of fish chromosomes. Westarp- Wiss, Magdeburg, 237 pp.
Levan A, Fregda K and Sandberg AA (1964) Nomenclature for centromeric position on chromosomes. Hereditas 52:201220.

Oliveira C, Almeida-Toledo LF, Foresti F, Britski HA and Toledo-Filho SA (1990) Comparative cytogenetic analysis of three cytotypes of Corydoras nattereri (Pisces, Siluriformes, Callichthyidae). Cytologia 55:21-26.

Oliveira C, Almeida-Toledo LF, Mori L and Toledo-Filho SA (1992) Extensive chromosomal rearrangements and nuclear DNA content changes in the evolution of the armoured catfishes genus Corydoras (Pisces, Siluriformes, Callichthyidae). J Fish Biol 40:419-431.

Oliveira C, Almeida-Toledo LF, Mori L and Toledo-Filho SA (1993a) Cytogenetic and DNA content in six genera of the family Callichthyidae (Pisces, Siluriformes). Caryologia 46:171-188.

Oliveira C, Almeida-Toledo LF, Mori L and Toledo-Filho SA (1993b) Cytogenetic and DNA content studies on armoured catfishes of the genus Corydoras (Pisces, Siluriformes, Callichthyidae) from the southeast coast of Brazil. Rev Brasil Genet 16:617-629.

Oliveira C and Gosztonyi AE (2000) A Cytogenetic study of Diplomystes mesembrinus (Teleostei, Siluriformes, Diplomystidae) with a discussion of chromosome evolution in siluriforms. Caryologia 53:31-37.

Reis RE (1998) Anatomy and phylogenetic analysis of the neotropical callichthyid catfishes (Ostariophysi, Siluriformes). Zool J Linn Soc 124:105-168.

Reis RE (2003) Family Callichthyidae (armored catfishes). In: Reis RE, Kullander SO and Ferraris Jr. CJ (eds) Check List of the Freshwater Fishes of South America. Edipucrs, Porto Alegre, pp 291-309.

Scheel JJ, Simonsen V and Gyldenholm AD (1972) The karyotypes and some eletrophoretic patterns of fourteen species of the genus Corydoras. Sonderdruck aus $\mathrm{Z}$ f zool Systematik u Evolutionsforschung 10:144-152.

Shimabukuro-Dias C, Oliveira C and Foresti F (2004) Karyotype variability in eleven species of the genus Corydoras (Siluriformes, Callichthyidae). Ichthyol Expl Freshwaters 15:135-146.

Sumner AT (1972) A simple technique for demonstrating centromeric heterochromatin. Exp Cell Res 75:304-306.

Torres RA, Foresti F and Oliveira C (1998) Comparative cytogenetic studies in alopatric populations of Trichomycterus paolence Eigenmann, 1918 from South-eastern Brazil (Siluriformes, Trichomycteridae). Cytologia 63:107-114.

Turner BJ, Diffot N and Rasch EM (1992) The callichthyid catfish Corydoras aeneus is an unresolved diploid-tetraploid sibling complex. Ichthyol Explor Freshwaters 3:17-23.

Associate Editor: Yatiyo Yonenaga-Yassuda 